\title{
Informatization and Informalization of Gender and Workforce, the Paradoxes of India's Growth and Development
}

\author{
M U Farooque, Sindhu Krishnan, Zeenat Perween
}

\begin{abstract}
The Labour is the natural prime factor of production,which produces and transform goods, services, economy, state, society and system from one form to another and cultivate the natural flora and fauna factors by their continuous physical and mental efforts for the survival of thehuman living being of the world. The living being, journey of numerous civilizations beyond the numeric counting and calculations has been working, inventing, innovating for a better life, society and system. This paper studies the manual traditional and modern mechanized agricultural and industrial evolution of Indian economy in the world contemporary times and assessing the various socioeconomic factors which has been the obstacle and challenging resistivefactors of economic growth transformation into the development, as the Indian economy has made tremendous growth in information technology and GDP since 1980 which is now the third biggest economy on PPP which didn't converted into the transformational development, which resulted into increase in sizes of vulnerable unorganized workers and decrease in the female participation rate in labour force (FPRLF) in the hyper economic growth regime, which has resulted into informalization of women and labour at large in post 1945 US structured capitalistic Washington consensus regulated major liberalized free market determined world has produced the paradox of India's high Economic growth with one worst Human Development.
\end{abstract}

Keywords: Paradox of India's Growth \& Development, Unorganized and Organized Labour, Intra and inter Colonization, Female Labour Participation Force.

\section{INTRODUCTION}

The starting of modern industrial revolution which changed the way of manual manufacturing to new mechanized manufacturing ways in the Europe, United States and contemporary others geographical places during 1760 to 1840 . The technical transition from manual hand based production to atomized machine based production in the field of chemical, steam power, coal and water power, consumer's goods, textiles and mechanical tools etc begin the revolution in the human lives. Textile has been the first industry been atomized with maximum capital investment, employment and production in Great Britain which shortly covers and hegemonies the industrial handicraft market of North and south America, west Indies, Indian Sub Continent especially India by the East India Company (EIC) trading and their politics.

Revised Manuscript Received on September 10, 2019.

Dr. M U Farooque, Formerly University of Delhi, Managing Editor THE MASS, A Quarterly Refereed Research Journal of Social Science, Delhi, India

(email: farooqueecon@gmail.com)

Sindhu Krishnan, Assistant Professor, Vidyalankar School of Information Technology, Mumbai, Maharashtra, India.

(emai: sindhu.krishnan@vsit.edu.in)

Er. Zeenat Perween, B.Tech, MBA, Independently Working for the Society, Technology and Development,India.

(email: siddiquezeenat94@gmail.com).
So the beginning of modern industrial revolution in Britain has gone to the major world which obviously has increased the Gross World Product (GWP) by Britain mechanize techniques and Colonization which raise the per capita income (PCI) of the peoples, although the British industrial revolution in many parts of the world and in India has ruined the ongoing indigenous artisanship industry. So, the emergence of manufacturing industry has started subsiding gradually till now the agricultural living dependency of people as the almost major prime source of production and living subsistence.

The phase of second industrial revolution has given the momentum to the production of iron \& steel, chemical, petroleum, automotive machine industry, electricity power production from 1850-1860 onward has reached united States, Germany, France, Italy etc from Great Britain. In the second phase of industrial revolution, the telephonic information a big technology has been invented during 1850-1876 andover the period of time it hasnow reached the ultra-satellite'schip based information, the most strongest factor of today's economy, state and society in hand to the contemporary times.

The mass production of goods has also paved way for the service sector production, the goods \& services, market, nation, intra-nation and inter-nation circulation has started the information technology production in the major society and system throughout the world. Eric. J. Hobsbawam 1969 says in his book Industry and Empire 1750 rightly connoted that the technology has transformed the life of people but at the same it has become inevitable that the technology has became the co-factor and instrument of capitalist by which they trapped the mass workers in the informal mechanical exploitive structure.

The capitalistic hegemonic information based colonization of Britain and United States, Canada, Brazil, Belgium, USSR, Australia, China, Denmark, Greece, Netherland, Norway, Yugoslavia, South Africaetc Allies got victory over Axis Powers of Germany, Italy, Japan, Hungary, Romania and Bulgaria etc evidences the rapid informatization of telephones, alone United States were using more than 20 million telephones during 1939-1945, it clearly suggest through the inferences that the informatization has given edge to the Allies forces in winning the long years of devastating war which tolled more than 85 million peoples about 3\% contemporary population of the world as par the official records of Royal 
Signal Museum of England 1930.

The fordism and informatization has led the mass production of goods and services in 1934, Gramsci Antonio in his easy "Americanism and Fordism, The fordism which has been used to boom the productive economy to transformed American and world society and system with established American capitalism over the world. Industrial revolution led mass production, colonization, informatization and Second World War and their consequences has instituted various institutions like United Nation Organization (UNO) 1945, International Monetary Fund (IMF) and World Bank-International Bank for Reconstruction and Development (IBRD) 1945, and world private agency American and European hegemonic funding agency of world bank group International Financial Corporation (IFC) 1956 and General Agreement on Tariff and Trade (GATTs) 1947, World Trade Organization (WTO) 1995, which has established the American controlled structure throughout the world.

The victorious Britain and United States has been the steering, regulator and determinant of all those institution in which regime the world is living is institutional colony has capitalized the whole world resources in every aspect, just for one example that over $70 \%$ international trade are being transacted in United States dollars \& European Euro and controlling more than $60 \%$ of world GDP. The estimate of Indian GDP during 1860-1960 by V K R V Rao and Krishna G. Saini found that real per capita GDP has been almost stagnant of Indian economy during the period. The phase of "Hindu Rate of Growth" studies, proposed and coined in 1978 by Professor Raj Krishna of Delhi School of Economics refer to the low level of $3.5 \%$ economic growth rate of India during 1950-1980 with about $1.3 \%$ of per capita increase in growth.

\section{COMPOSITION AND DIRECTION OF INDUSTRIAL POLICY RESOLUTIONS (IPR) IN INDEPENDENT INDIA}

The one strongest factor of India's growth and Development which has determined the contemporary conditions of economy, state, society, system and its all sections, genders and ages of people has been its policy and especially the Industrial Policy Resolutions (IPR) which has been revised time to time as par the requirement and government understanding and priorities.

IPR 1948The very first major industrial policy resolution (IPR) after the independence of India came, when the constitution were in the process of writing and passing, mostly the most of the constitution has been passed through the unanimous consensus of constituent assemblyexcept few like Languages subjects and others, the 1948 industrial policy is the first document which says that the structure of Indian Economy will be of mixed types of both public and private productions, distribution and consumptions. The IPR 1948 and framing structure of Indian Economy has been shaped in the tone and guidance of United States IMF, IBRD, GATTs and IFC objective, it's not that we are finding the mixed open model of economy has been challenging but the way of Capitalistic colonial west has captured the Indian economy, state, society and system for longer till now and ongoing onwards through their capital and capitalistic cartel geopolitical institutional.

IPR 1956 the second major industrial policy has been concentrated and focused on the heavy industrialization means government major investment has been made in few heavy industries ignoring the vast agriculture, health and education sectors, where as the European, American and all other contemporary developed region has in their initial starting phase has firstly given priority to their basic agriculture, health and elementary education because the basic construction of capabilities depends on required nutrition, basic health and education which become the base factors for robust growth and over all development, the major heavy investment in few heavy industries on the cost of the India's vast economic basic needs of agriculture, health and education has been trapped the Indian economy for long over three decades from 1950-1980 in the low level of economic growth at about $3.5 \%$ referred as " Hindu Rate of Growth"by Professor Raj Krishna in 1978. The main reason of the three decades lowest rate of economic growth was the following the US based controlled international institution like IBRD of investing in non human based factors of heavy industries which has not trickle down the growth and development at larger level which was the punching line and clarion of the contemporary government and governments aligned few big sycophants academician of the contemporary period.

IPR 1977 the first non congress government led by Morarji Desai and Industry Minister George Fernandes has stopped the pattern of earlier ongoing industrial policy and ongoing heavy investment in only few heavy industries and brought the small scale and village based industrial policy focusing on agriculture, health and basic educations, this industrial policy has prepared some base for triggering the economy into high and hyper growth as from 1979 onward, the economy has taken the hyper growth rates which is still ongoing towards high and higher rates as the potentiality of Indian economy growth is still immense there as the productivity rates of agriculture, industry and service sector is still far behind the international level, where as India has highest young skilled working population and market so reaching at the par of international productivity rates will make Indian Economy as the Biggest Economy in the world, the prior conditions to be followed for becoming the biggest economy is taking care growth transformation into human development, a big growth without the proportional human development, gender development is nothing but it merely the internal capital colonization which more disturbing and problematic for any concerned region of the world.

IPR 1980 as the congress government came back in power and stopped the ongoing investment of IPR 1977 and brought back the earlier pattern of 1956 policy of investment in the big industries which prepared way for liberalization of economic system from state to free market.

IPR 1991has fully liberalized from state commanding economy of compulsory licensing, protective regulations, locations etc and opened the Indian Economy into 
capitalistic world economy for attracting the investment for supporting financially suffering cotemporary conditions, Productions and increasing the exports. The policy of Liberalization, Privatization and Globalization (LPG) of second generation reform has objectively targeted the high growth which has been achieved too but the growth did not transformed into development that's why in domestic economic production sizes on the purchasing power parity (PPP) basis has gown a lot but in development its ranking still lagging far behind the basic needs at 130 out 189 countries in HDI in 2018. A growth which didn't convert into development of economy, state, society and people are merely increasing the numbers having no meaning, so the transformation of development with state policies is most important.

So the studies and analysis of major industrial policies suggests that there has been continuous focus on the growth in the production of goods and services including information services but these growth has not ensured to access and reaches to its people so the rate of growth could have been responded the same in rate of development, that's why in the hyper growth regime the vulnerability of organized labour has been increased as the share of organized sector labour has been decreased in higher growth rate than the earlier low growth rate were more share of organized labour, it strongly inference that vulnerability of workers has led to capitalism.

\section{OBJECTIVES OF INFORMATIZATION AND INFORMALIZATION}

This paper studies the evolution of industrial working, transition, transformation in modern times of contemporary period of trans world relation, informatization, informalization of labour in the pre-colonial, colonial and post colonial of modern nation-state system under post 1945 international organizations like UNO, GATTs, IMF, IBRD, IFC, IDA, ICSID, MIGA etc and intra India policy changing regime.

Firstly this research paper studies and assess the working conditions of Indian Labour, whose magnitude and extent of its working in informal and unorganized sector has been increased over the period of times in modern information technology which is one most contradicting of development of information technology and increase in informalization of society and system of its workings, thus prima facie its proves on the numeric basis that the intent of information has not been used properly by society, system and regulatory world to formalize the working and its livelihoods by incorporating in the production of goods and services to women, children and all.

Secondlythis paper studies the working conditions of women and assessing the factors of female participation in Labour force in Indian Labour market, primarily it has been observed that the participation of female in employment has been decreased is one most worrying subject for any continuously growing nation and economy like India which is one third biggest size of economy on real exchange rate and purchasing power parity (PPP) with one of the highest domestic production (GDP) growth rate in the world.

Thirdlythis paper studies the long way to the working of information technology, hyper growth, mass production and their justifiable reward to their factors of production. The contemporary government factors which determine the state liquidity and national income flows has been liberalized throughout the major world during seventies which finally has submitted the state economic command to free market control owning by the few cartelist capitalist group throughout the major US directed world of Asia, Europe, America and whole of Africa.

\section{RESEARCH METHODOLOGY \& RESULTS}

The qualitative socioeconomic factors with simple quantitative measuring the domestic production (GDP) growth rates and its comparing transformational impact on the basic indicator of development like health, education, employment has been used to studied and analyzed with the area of informatization, informalization and working conditions of workers and rising factors of capitalism.

Labour Force Participation Rate (LFPR) in Indian Labour Market (2009-18)

\begin{tabular}{|c|c|c|c|}
\hline Years & LFPR \% & GDP Rates\% & $\begin{array}{c}\text { Unemployment } \\
\text { Rate\% }\end{array}$ \\
\hline $2009-10$ & 54.92 & 6.8 & -- \\
\hline $2010-11$ & 54.09 & 8.4 & 3.8 \\
\hline $2011-12$ & 53.15 & 6.81 & 3.8 \\
\hline $2012-13$ & 52.25 & 05 & 4.7 \\
\hline $2013-14$ & 52.25 & 6.6 & 4.9 \\
\hline $2014-15$ & 52.24 & 7.2 & 5 \\
\hline $2015-16$ & 52.20 & 7.6 & 5 \\
\hline $2016-17$ & 52.13 & 8.2 & 3.9 \\
\hline $2017-18$ & 52.04 & 7.17 & 6.1 \\
\hline $2018-19$ & 51.92 & $7 *$ & $6^{*}$ \\
\hline
\end{tabular}

Source: World Bank Report 2919, CSO, NSSO, Ministry of Labour and other reports 2019

The group of working population comprises in the age group of 16-64 in the economy, who are currently employed or seeking an employment is called LFPR. The labour force participation rate is measured or calculated by taking the number of employed person divided by the total adult population and multiplying by 100 to get the results on percentage basis.

An analysis of a decade of labour force participation rate (LFPR) in the Indian labour and employment market clearly indicates the trends is decaling continuously since 2009 to 2018, the same period has witnessed high economic growth which didn't create the additional employment by additional high economic growth which resulted into the jobless economic growth and rises the income inequality and labour vulnerability and informality in economy, state, society and system, which clearly showing the role of labour has been hegemonies by capital factors of few capitalist.

\section{DECLINING WOMEN LABOUR FORCE PARTICIPATION RATE IN INDIA}

The half of human resources belonging to women gender that requires equal and inclusive participation in different economic, social and political activities which ensure the gender justice, inclusive growth and development According to NSSO 61st round of 2005 and 68th round of

Published By 
2018 on employment and unemployment survey and the World Bank report on Labour Force Participation Rate (LFPR) among the female in India has declined to $26.97 \%$ in 2018 from $36.78 \%$ in 2018.

Indian economy prior to independence from 1900-1947 had witnessed the pathetic $0.07 \%$ per capita growth rate, during 1947-64 the CAGR for India's GDP per capita had been $1.68 \%$. The phase of substantial higher economic growth since 1980 to 2019 has witnessed in decreasing the female labour participation, so the high growth has not transformed the women employment andoverall development.

\section{GOVERNMENT \& PRIVATE JOBS SIZE IN INDIA}

In 2018-19 there were 2.7\% government Job has been Central government and rest $97.30 \%$ has been concentrated in private sector entrepreneur, ventures, agriculture and factories and information technology services and manufacturing firms and industry, so it clearly shows among the working there are only $2.7 \%$ people are working in government sector and majority over $97 \%$ are working nongovernment sector as government didn't created jobs in their corporations and administrations which has led the unorganized sector working to 945 of total work force.

\section{PARADOX OF INCREASING VULNERABLE LABOUR FORCE AND HYPER GROWTH REGIME OF INDIAN ECONOMY}

The nascent information technology in Indian economy many IT enterprises with TATA group in 1967 in Mumbai with other contemporary firms at other places like Calcutta, Delhi, Hyderabad, Jamshedpur etc in India.

SantaCruz Electronics Export Processing Zone (SEEPZ) was established as a special economic zone (SEZ) in 1973 in Mumbai to promote the information and technology exports and attracting and securing foreign investment and simultaneous development of domestic information and technology market.

The information and technology share contribution to the GDP of India has been increased from $1.2 \%$ in 1998 to $7.7 \%$ in 2017.

According to National Association of Software and Services Companies (NASSCOM) the total revenue generation by the information and technology is US \$ 160 billion dollars in 2017 in which US \$ 99 billion dollars made through exports and the domestic revenue is growing at $13 \%$ rates in 2016-2017.

The over $67 \%$ total export of India goes to United States of America (USA), it became possible because of skilled and cheap IT workers in India. India is one biggest IT exporter in the world. Though the problem of IT workers is too very serious concern has been well described by Loy \&Ageson 2018 in their book The Creative Economy Entrepreneur from Start Up to Success: How Start Up in the Creative Industries are Transforming the Global Economy.

The problem of working hours, working whole nights as par the US \& European and Global real working hours in concentrated in local self-government, state government and has been started growing in the organized way by setting of

non regulated industries which mostly large numbers of cutting edge workers works under wages without the job security and all, which forms large numbers of software the most advance technology based works too largely in unorganized sector. So the issue of today's highest technology sector increasing rates of informalization is the real paradox to the hyper economic growth regime when there are over 40 crores smart phone \& internet users in the country in 2018, this increasing informalization is happening at the same vulnerability of working class has worsen due to the Indian State weak and non regulation and free capitalistic market advocacy needs to urgently solved by structural transformation of all round of workers for a better growth with meaningful development.

\section{UNORGANIZED SECTOR WORKING IN INDIA}

The unorganized sector workforce rate is increasing at the faster pace in the neo-liberal hyper economic growth regime of India along with the major free market developing world. The structure of the world economic system after winning the Second World War by the United States and their Allies, set-up the US controlled \& regulated market international organization like UNO, IMF, IBRD, GATTs, WTO andWashington consensus of neo-liberal free market and pre-independence cartel capitalistic working of spotted discussed Bombay Plan proposal of continuing the non-state intervention and carry the free market system of Private Ownership of nation working and activities which the interim government didn't accept completely but partially it has been incorporated by incorporating the mixed form of economic system, the Bombay plan has been published in 1944-45 which was the proposal of eight dominant capitalist and capitalist advocate of the contemporary times (J R D Tata, G D Birla, A Dalal, Sri Ram, K Lalbhai, A D Shroff, P Thakurdas\& John Mathai).

The partial pursuance of Bombay plan has been gradually and consistently trapped the whole economic system into their fold of full control in free market operation as wellconcentrated the mass production and growth in few capitalistic shelf and self. This is the reason India even being the third biggest economy on the real exchange rates or purchasing power parity its human development indicators like nutrition, primary, secondary educational conditions (Geeta Kingdon 2007) are so pathetic, major health indicator like maternal mortality rates, infant mortality rates, anemia and the employment vulnerability conditions of extent and sizes of unorganized sector in India and Nepal is worst in the world (ILO Report), its crystal clearly shows being economic third richest country even on per capita income basis on PPP India is equal to west Asian country like Uzbekistan but in development indicator its far behind, country like Kyrgyzstan having less than half per capita income of India having far better development indicator it clearly shows that the India's GDP growth has not been managed to transform its development as still more than $40 \%$ its population are suffering malnutrition and anemia, 
only about $25 \%$ young are being enrolled into higher education i.e, gross enrollment ratio of higher education just $25 \%$ in 2019 , its just enrolment rates through all medium of regular and distance mode college, institute and university, 94\% workforce is working in vulnerable unorganized sector as par national commission for enterprises in unorganized sector (NCEUS 2004) headed by Professor Arjun Sengupta and Various NSSO reports of 1983-2018.

Working Sizes in Organized \& Unorganized Sector 1983-2019, Table - 2

\begin{tabular}{|c|c|c|}
\hline Years & Organized Sector \% & $\begin{array}{c}\text { Unorganized Sector } \\
\text { \% }\end{array}$ \\
\hline $1983-84$ & 8.0 & 92.00 \\
\hline $1987-88$ & 7.8 & 92.20 \\
\hline $1993-94$ & 7.3 & 92.70 \\
\hline $1999-00$ & 7.0 & 93.00 \\
\hline $2018-19$ & 6.0 & 94.00 \\
\hline
\end{tabular}

Source: Various reports of NSSO, NCEUS, World Bank \& EPW May 27, 2006

The above table number 2 describing the organized and unorganized sector is clearly showing that since 1983-84 there has been continuous decline in the organized sector employment, whereas the same period has made robust economic growth, the simple and very clear inference is that Indian state has not regulated the prime factors of production labour market with its dignified and rewards and various social security instead it has left it to the free capitalistic market rightly discussed by Saratchand (March 2019) in some macroeconomic theoretical foundations of jobless growth that the free market capitalist economy flowing its earned capital away from the labour market raise the vulnerable increase in the size of unorganized labour in the economic system.

\section{SUGGESTIONS}

The basic socioeconomic indicator has been studied well especially from 1980-2019, the phase of the high growth of information technology, gross domestic production (GDP) and global economic integration, it has been observed that the high economic growth and informatization has not proportionally transformed the labour and gender market instead the high economic growth has adversely affected the formal labour and gender ongoing rates of low economic growth phase of 1950-80.

This shows the state labour regulation has been freed it to free market which has soaked the productivity and production major benefit to few cartelist capitalist section which has emerged the various resistance from the poor, marginalized section described by Professor Alpa Shah (Night March 2018) of London Scholl of Economics.

In short we see it as the paradox of growth and development as the higher economic growth has worsen the conditions of labour and decreased the female participation rates into the workforce and increased the sizes and rates of vulnerable informal unorganized workforce and made and established few as the global owner type capitalists.

The Indian state must sternly start the state based people accessible welfare regulation to incorporate female labor force and overall labour force into the formal organized sector by transforming the hyper economic growth and informatization into development, else merely the high growth without proportional development will be categorized as the intra-colonization.

\section{CONCLUSION}

Emile Durkhiem rightly said in his famous manuscript "Division of Labour in the Society" 1893 the bonds of economic co-operation and incorporation into organized state economic activities and regulations forms the very foundations of human and social life. We are sure this study will encourage the peoples and states to foster the ways to incorporate and transform the economy, state, society, system, gender and peoples as the satisfied participant into the nature's infinite common arena as rightly said by Dreze (2019) we have to think and make beyond oneself concentrated or we are doomed.

\section{REFERENCES}

1. Dreze, Zen(2019): Sense and Solidarity; Jholawala Economics for all; Oxford

2. Durkhiem, Emile (1893):, Division of Labour in the Society"

3. Farooque, M. U., (2009): Social Security for Unorganized Working in India; Third World Impact Jan March pp 24-27

4. Farooque, M. U., (2009): Social Security and Constitutional Provision for Unorganised Worker in India; The Mass A Quarterly Research Journal of social science- Patna; Apr- Jun. pp 1-2

5. Farooque, M. U., (2009): Impact of Climate Change on Indian Agriculture: An Environmental Analysis; The Mass A Quarterly Research Journal of social science Patna

6. Gramsci, Antonio (1934): Americanism and Fordism; Prision Notebook

7. Hobsbawn, Eric J; (1969) Industry and Empire; Penguin Books

8. Krishna, Raj (1978); Hindu rate of growth

9. Mishra, U.S and Nadeem Hussain (2018); Introducing Social-Cultural Anthropology, JPD- New Delhi

10. Royal Signal Museum (1930) England, Documents on Telecom use in Second World Wars by Allies Forces

11. Rao V KR V (1930-80) Changes in India's National Income

12. Shah, Alpa (2018); Night March; Harpar Collins Publishers India

13. Sainath, P (2017); Everyone Loves Good Drought; Penguin

14. Sen, Amartya (2006); The Argumentative Indian; Penguin

15. Sen, Amartya (1999); Development as Freedom; Oxford

16. Sen, Amartya (2009); The Idea of Justice; Penguin

17. Samir Amin (1971); Accumulation on World Scale

18. Samir Amin (1973); Unequal Development

19. Samir Amin (2003); The Liberal Virus

20. Saratchand, C (2019);Some Macro-theoretical Foundations of Jobless Growth; Economic \& Political Weekly 